\title{
An exploration investigation on important factors influencing e-marketing: Evidence from banking industry
}

\author{
Fatemeh Karimi Anche, Somayeh Hozouri* and Amir Hossein Mehdizadeh Hanjani
}

Department of Management, Islamic Azad University, South Tehran Branch, Tehran, Iran

\begin{tabular}{l}
\hline C H R O N I C L E \\
\hline Article history: \\
Received June 10, 2013 \\
Received in revised format \\
25 August 2013 \\
Accepted September 262013 \\
Available online \\
October 14 2013 \\
\hline Keywords: \\
E-marketing \\
Factor analysis \\
Banking industry
\end{tabular}

\section{A B S T R A C T}

During the past few years, electronic marketing has gained significant portion of market share in the world. People become familiar with various products and services through the magic of internet and they could make their purchase with an ease of a click of a button. This paper presents an investigation on important factors influencing e-marketing in banking industry in city of Tehran, Iran. The proposed study designs a questionnaire in Likert scale consists of 19 questions, distributes it among 250 Iranian experts and analyzes it based on principal component analysis. During the survey, the numbers of questions are reduced to 16. Cronbach alpha is calculated as 0.90 and Kaiser-MeyerOlkin Measure of Sampling Adequacy and Approx. Chi-Square are 0.939 and 2938, respectively. Based on the results of our survey, we have derived two factors including environmental factors as well as information technology.

\section{Introduction}

E-business has become an interesting area of research since it has become an essential part of marketing planning (Kımıloğlu, 2004; Ellis-Chadwick et al., 2009; Meng, 2009; Salehi et al., 2012; Fortin et al., 2012). The digital business, on the other hand, represents recent advances of the business contexts and the one with the bigger needs of differentiation of the mix. Dominici (2009) clarified different approaches to marketing mix evolution through a review of various literatures on emarketing mix, concentrating on the development of marketing mix theory for the digital context. According to Raoofi (2012), in the modern world, applying technology in the marketing activities of all sorts of organizations have increased and it is important to understand the extent to which electronic marketing moderates the effect of market orientation on firm marketing competencies which are, in turn, associated with firm performance. During the past few years, social web pages have played essential role on e-marketing. Hsu (2012), for instance, reported that Facebook could be considered as international e-marketing strategy of Taiwan hotels.

* Corresponding author. Tel.: +989125367924

E-mail addresses: saho84@rocketmail.com (S. Hozouri)

(C) 2014 Growing Science Ltd. All rights reserved. doi: $10.5267 /$ j.uscm.2013.10.002 
Raoofi (2012) designed a survey to investigate how e-marketing moderates market orientation from the marketing competencies relationship on the marketing competencies along with firm performance relationship on the other ones. The study was performed on 100 manufacturing owner-managers in Iran and the results disclosed that e-marketing could translate more into firm performance when supported by organizational culture and behavioral dispositions like market orientation. In addition, they reported that e-marketing could also moderate the relationship between marketing competencies and firm performance. The study also discussed the managerial and public policy implications of the findings.

Although e-marketing is mostly prevalent but there are few templates for managers who wish to apply the Internet/Web and related information technologies to market their products and services. Krishnamurthy (2006) provided managers with a comprehensive, actionable, and practical methodology (E-MARKPLAN) to plan, enact, and analyze e-marketing activities. Sadiq Sohail and Shanmugham (2003) investigated the current trends in the e-commerce revolution, which has set in motion in the Malaysian banking sector and reported on an empirical research carried out in Malaysia to shed light on the customers' preference for electronic banking and the factors. They reported that while there had been no significant differences between the age and educational qualifications of the electronic and conventional banking users, some differences were detected on other demographic variables.

Hamidi and Safabakhsh (2011) investigated the impact of information technology on e-marketing by gathering the necessary data from the balance sheet and income statement of various firms including government agencies. They reported different factors influencing the success of information technology including providing the opportunity at every place and time for advertisement; increasing the overall potential of advertisement; increasing the income for the companies; and decreasing the pollution and energy consumption.

Shaltoni and West (2010) performed an investigation on the measurement of e-marketing orientation (EMO) in business-to-business markets. They suggested that EMO was made up of both philosophical and behavioral components. By conceptualizing EMO and facilitating its measurement, marketers helps benchmark their activities towards adoption, evaluate their efforts and assess where to concentrate their resources to improve their e-marketing processes.

Trainor et al. (2011) investigated the integrating information technology and marketing by performing an examination of the drivers and outcomes of e-Marketing capability. Rahimnia and Hassanzadeh (2013) investigated the effect of website content, including informational and design dimensions, on the effectiveness of e-marketing and e-trust as mediator variables. These characteristics were examined with reference to sales and marketing division managers in a sample of 100 commercial saffron corporations in the Khorasan province. They reported that website content could influence on e-marketing and e-trust and that e-trust played an essential mediating role in the relationship between e-trust and e-marketing effectiveness.

Luna et al. (2003) investigated the effect of language, graphics, and culture on bilingual consumers' Web site and product evaluations. They extended previous bilingual memory research to affective responses and to a new medium - the Internet. The stated that attitudinal measures were influenced by the interaction of Web site language with two kinds of congruity including graphic congruity and cultural congruity and concluded from that both kinds of congruity could influence bilinguals attitude-formation processes. Teo (2005) investigated the usage and effectiveness of online marketing tools among Business-to-Consumer (B2C) firms in Singapore. 


\section{The proposed study}

This paper presents an investigation on important factors influencing e-marketing in banking industry in city of Tehran, Iran. The proposed study designs a questionnaire in Likert scale consists of 19 questions, distributes it among 250 Iranian experts and analyzes it based on principal component analysis. During the survey, the number questions are reduced to 16. Cronbach alpha is calculated as 0.90 and Kaiser-Meyer-Olkin Measure of Sampling Adequacy and Approx. Chi-Square are 0.939 and 2938, respectively. Fig. 1 demonstrates the results of Scree plot.

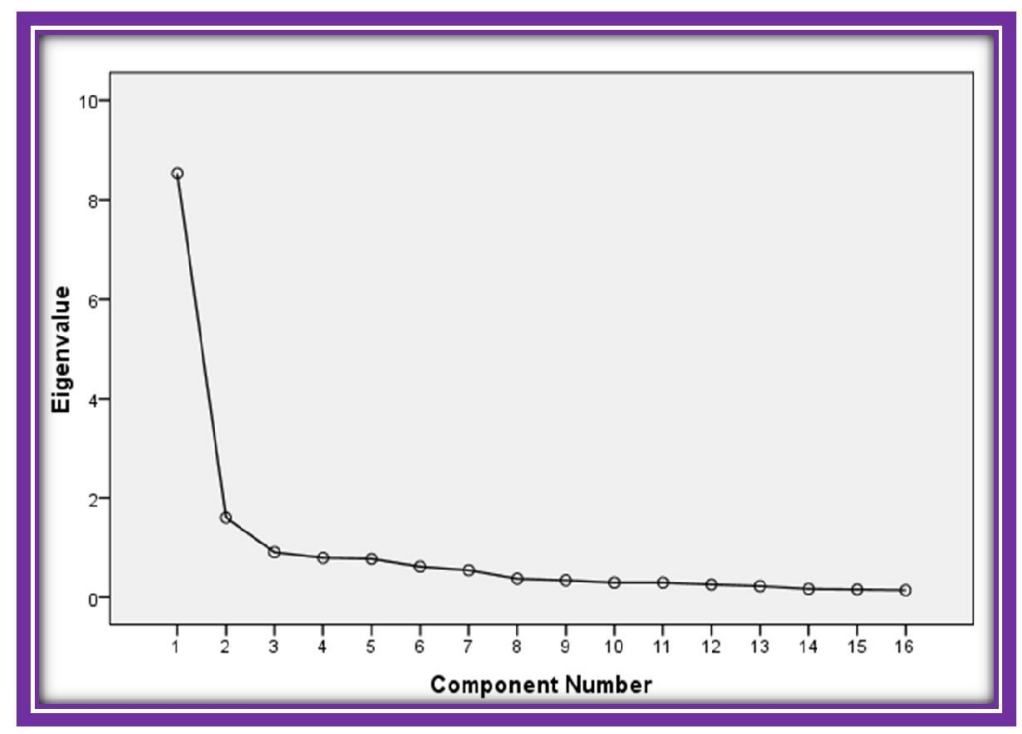

Fig. 1. The summary of Scree plot

As we can observe from the results of Fig. 1, there are two factors, which could be extracted for further studies. In addition, as we can observe from the results of communalities given in Table 1, most factors are well above the minimum acceptable level of 0.5 . Table 2 demonstrates the results of factor analysis on these factors.

Table 1

The summary of communalities

\begin{tabular}{llc}
\hline & Initial & Extraction \\
\hline VAR00003 & 1.000 & .806 \\
VAR00004 & 1.000 & .786 \\
VAR00005 & 1.000 & .617 \\
VAR00006 & 1.000 & .667 \\
VAR00007 & 1.000 & .678 \\
\hline VAR00008 & 1.000 & .554 \\
VAR00009 & 1.000 & .627 \\
VAR00010 & 1.000 & .639 \\
VAR00011 & 1.000 & .511 \\
VAR00012 & 1.000 & .557 \\
VAR00014 & 1.000 & .615 \\
VAR00015 & 1.000 & .534 \\
VAR00016 & 1.000 & .748 \\
VAR00017 & 1.000 & .623 \\
VAR00018 & 1.000 & .646 \\
VAR00019 & 1.000 & .528 \\
\hline
\end{tabular}


Table 2

The summary of principal component analysis after rotation

\begin{tabular}{|c|c|c|c|c|c|c|c|c|c|}
\hline \multirow[t]{2}{*}{ Component } & \multicolumn{3}{|c|}{ Initial Eigenvalues } & \multicolumn{3}{|c|}{ Extraction Sums of Squared Loadings } & \multicolumn{3}{|c|}{ Rotation Sums of Squared Loadings } \\
\hline & Total & $\%$ of Variance & Cumulative $\%$ & Total & $\begin{array}{c}\% \text { of } \\
\text { Variance }\end{array}$ & $\begin{array}{c}\text { Cumulative } \\
\%\end{array}$ & Total & $\begin{array}{c}\% \text { of } \\
\text { Variance }\end{array}$ & $\begin{array}{c}\text { Cumulative } \\
\%\end{array}$ \\
\hline 1 & 8.533 & 53.331 & 53.331 & 8.533 & 53.331 & 53.331 & 7.355 & 45.971 & 45.971 \\
\hline 2 & 1.604 & 10.026 & 63.357 & 1.604 & 10.026 & 63.357 & 2.782 & 17.386 & 63.357 \\
\hline 3 & .906 & 5.662 & 69.019 & & & & & & \\
\hline 4 & .793 & 4.958 & 73.977 & & & & & & \\
\hline 5 & .773 & 4.828 & 78.805 & & & & & & \\
\hline 6 & .616 & 3.850 & 82.655 & & & & & & \\
\hline 7 & .542 & 3.386 & 86.041 & & & & & & \\
\hline 8 & .372 & 2.324 & 88.365 & & & & & & \\
\hline 9 & .339 & 2.117 & 90.482 & & & & & & \\
\hline 10 & .293 & 1.833 & 92.315 & & & & & & \\
\hline 11 & .293 & 1.831 & 94.145 & & & & & & \\
\hline 12 & .254 & 1.587 & 95.732 & & & & & & \\
\hline 13 & .222 & 1.387 & 97.119 & & & & & & \\
\hline 14 & .166 & 1.037 & 98.156 & & & & & & \\
\hline 15 & .155 & .968 & 99.124 & & & & & & \\
\hline 16 & .140 & .876 & 100.000 & & & & & & \\
\hline
\end{tabular}

Based on the results of our survey, we have derived two factors including environmental as well as information technology issues.

\section{The results}

In this section, we present details of our findings on five influencing factors.

\subsection{The first factor: Environment issues}

The first factor is associated with environment issues. Table 3 demonstrates details of our study. As we can observe from the results of Table 3, "Marketing capabilities" is the most important factor, followed by "Having a good access and ease of use", "Direct response", "Difficulty in execution" and "Customer skills".

Table 3

The summary of factors associated with environment analysis

\begin{tabular}{llccc}
\hline Option & Factor weight & Eigenvalues & \% of variance & Accumulated \\
\hline Marketing capabilities & 0.844 & 3.489 & 68.223 & 68.223 \\
Social web pages & 0.744 & & \\
Trust & 0.730 & & \\
Having a good access and ease of use & 0.814 & & \\
Direct response & 0.784 & & \\
Difficulty in execution & 0.750 & & \\
Relationship with customers & 0.574 & & \\
Employee acceptance & 0.684 & & \\
Customer skills & 0.750 & & \\
Technical skills & 0.744 & & \\
\hline Cronbach alpha $=0.82$ & & & \\
\end{tabular}

\subsection{The second factor: Information technology components}

Information technology factors are the second important issues and they include three factors, which are summarized in Table 4 as follows, 
Table 4

The summary of factors associated with infrastructure components

\begin{tabular}{llccc}
\hline \multicolumn{1}{c}{ Option } & Factor weight & eigenvalues & \% of variance & Accumulated \\
\hline Having a good access to information & 0.746 & 3.031 & 52.767 & 52.767 \\
Online advertisement & 0.726 & & & \\
Email advertisement & 0.646 & & & \\
\hline Information technology & 0.546 & & \\
Software packages & 0.728 & & \\
\hline Better awareness & 0.688 & & & \\
\hline Cronbach alpha $=0.69$ & & & & \\
\hline
\end{tabular}

According to the results of Table 4, "Having a good access to information" is number one priority followed by "Software packages" and "Online advertisement".

\section{Conclusion}

This paper has presented an investigation on important factors influencing e-marketing in banking industry. The proposed study of this paper has used principle component analysis and it has detected two factors of environmental factors as well as information technology based issues. The first factor includes ten sub-components including Marketing capabilities, Social web pages, Trust, Having a good access and ease of use, Direct response, Difficulty in execution, Relationship with customers, Employee acceptance, Customer skills and Technical skills. The second factor also includes Having a good access to information, Online advertisement, Email advertisement, Information technology, Software packages and Better awareness.

\section{Acknowledgment}

The authors would like to thank the anonymous referees for their construction comments on earlier version of this work.

\section{References}

Dominici, G. (2009). From marketing mix to e-marketing mix: a literature overview and classification. International journal of business and management, 4(9), 17-24.

Ellis-Chadwick, F., Mayer, R. E., \& Johnston, K. J. (2009). Internet marketing: strategy, implementation and practice. D. Chaffey (Ed.). Pearson Education.

Fortin, D. R., Dholakia, R. R., \& Dholakia, N. (2002). Emerging issues in electronic marketing: thinking outside the square. Journal of Business Research, 55(8), 623-627.

Hamidi, A., \& Safabakhsh, M. (2011). The impact of information technology on emarketing. Procedia Computer Science, 3, 365-368.

Hsu, Y. L. (2012). Facebook as international eMarketing strategy of Taiwan hotels. International Journal of Hospitality Management, 31(3), 972-980.

Kımıloğlu, H. (2004). The "e-literature": A framework for understanding the accumulated knowledge about Internet marketing. Academy of Marketing Science Review, 4(6), 1-37.

Krishnamurthy, S. (2006). Introducing E-MARKPLAN: A practical methodology to plan e-marketing activities. Business Horizons, 49(1), 51-60.

Luna, D., Peracchio, L. A., \& Dolores de Juan, M. (2003). The impact of language and congruity on persuasion in multicultural e-marketing. Journal of Consumer Psychology, 13(1), 41-50.

Meng, X. (2009). Developing model of e-commerce e-marketing. In Proceedings of the 2009 International Symposium on Information Processing (ISIP'09), Huangshan, PR China, August (pp. 21-23). 
Raoofi, M. (2012). Moderating role of e-marketing on the consequences of market orientation in Iranian firms. Management \& Marketing-Craiova, 2, 301-316.

Rahimnia, F., \& Hassanzadeh, J. F. (2013). The impact of website content dimension and e-trust on emarketing effectiveness: The case of Iranian commercial saffron corporations. Information \& Management, 50(5), 240-247.

Sadiq Sohail, M., \& Shanmugham, B. (2003). E-banking and customer preferences in Malaysia: an empirical investigation. Information Sciences, 150(3), 207-217.

Salehi, M., Mirzaei, H., Aghaei, M., \& Abyari, M. (2012). Dissimilarity of E-marketing VS traditional marketing. International Journal of Academic Research in Business and Social Sciences, 2(1), 814-825.

Shaltoni, A. M., \& West, D. C. (2010). The measurement of e-marketing orientation (EMO) in business-to-business markets. Industrial Marketing Management, 39(7), 1097-1102.

Teo, T. S. (2005). Usage and effectiveness of online marketing tools among Business-to-Consumer (B2C) firms in Singapore. International journal of information management, 25(3), 203-213.

Trainor, K. J., Rapp, A., Beitelspacher, L. S., \& Schillewaert, N. (2011). Integrating information technology and marketing: An examination of the drivers and outcomes of e-Marketing capability. Industrial Marketing Management,40(1), 162-174. 